\title{
Using the ARDL Approach to Explore the Effect of Chinese Individual Mobility in Australian Residential Real Estate Market
}

\author{
Po-Jui $\mathrm{Wu}^{*}$ \\ School of Business \\ Macau University of Science and Technology \\ Macau, China \\ pjwu@must.edu.mo
}

\author{
Kwo Ping Tam \\ School of Business \\ Macau University of Science and Technology \\ Macau, China \\ kptam@must.edu.mo
}

\begin{abstract}
To better understand whether Chinese mobility has a significant effect on the Australian residential real estate market, the relationship between Chinese individual mobility and Australian residential real estate market is explored. The Autoregressive Distributed Lag (ARDL) approach is employed to investigate the cointegration relationship of the variables, including Chinese tourism mobility, Chinese temporary migration mobility, Australian residential real estate prices and the Australian real estate construction. The primary finding is that Chinese tourism mobility and temporary migration mobility does not have a significant and positive effect on Australian residential real estate prices, but Chinese tourism mobility contributes to the development of the Australian real estate construction in the long run. In terms of the short run, Chinese tourism mobility and temporary migration mobility lead to an increase in Australian residential real estate prices and have a negative effect on the Australian real estate construction. It is believed that understanding the effect of Chinese individual mobility in the Australian residential real estate market will assist policymakers or researchers to make reasonable policies or methods to solve affordability issues caused by high residential real estate prices.
\end{abstract}

Keywords-Chinese tourism mobility; Chinese temporary migration mobility; Australian residential real estate market; ARDL model

\section{INTRODUCTION}

Mobility is used in different forms, which included the movement of trade, investment and knowledge. In this paper, it is focused on individual human mobility, and particularly on the mobility of tourism and temporary migration. With the development of globalisation, the number of tourists and temporary residents has sharply increased [1]. This kind of mobility occurs in many western countries: people travel and stay in tourist destinations, where they are likely to purchase a residential real estate for a leisure life [2]. However, there is the emerging and expanding middle class in Asian developing countries. The flow of individual mobility from developing countries to developed countries has become more prominent recently. The individual mobility of tourism and temporary migration possibly contribute to potential foreign investors to have information about the investment opportunities.
Similarly, with the development of the economy and the expanding middle class, the Chinese individual mobility experienced a sharp increase. Chinese middle class tourists and temporary residents are particularly active in researching investment opportunities in residential real estate markets of different countries, especially in western countries, such as the United States, Canada and Australia [3] [4][5]. Australia is one of the favour investment destinations for Chinese investors with considering institutional and environmental issues, spatial tension, land scarcity and quality of life [6][7][8]. Australian real estate is categorised as a superior good with the characteristic of real estate ownership rights usually signifying 'superiority' in resources and usually accompanied by prestige [9]. As a result, the volume of Chinese investment in Australia real estate sharply increased in 2015-2016 and amounted to A \$31.9 billion. There has been caused discussion and debate about the research topic of Chinese investment in the Australia residential real estate market, such as the politics of Chinese investment and Chinese investors' strategies in Australia with qualitative method [5][10]. However, it is still questionable that Chinese mobility has a significant effect on the Australian residential real estate market. The major motivation for conducting this paper relates to the issues associated with the interaction between domestic owners and Chinese mobility in the Australian residential real estate market. It has often been the case that domestic owners believe that prices increases and affordability issues in the Australian residential real estate market are caused by Chinese investors. As a result, domestic owners and the Australian community feel uneasy with the situation, and believe that Chinese mobility should be controlled to avoid the housing prices up. Therefore, the aim of this study is to investigate the relationship between Chinese individual mobility and the Australian residential real estate market.

\section{LITERATURE REVIEW}

\section{A. Chinese Tourism Mobility and Temporary Migration Mobility in Australia}

With China's go out policy and the expanding middle class and super-rich people in China, there is an increasing number of Chinese tourists travelling Australia from around $\$ 29600$ annually in 1994 to more than 1200000 in 2016 . International 
tourism mobility facilitates potential foreign investors to gain a first-hand experience in the travelling countries, such as environment, work, ethic and culture, as well as to have information about the investment opportunities [11]. International tourism mobility has been believed as an important factor impacting foreign residential real estate investment [12].

Additionally, Chinese temporary residents experienced a sharp increase. Chinese international students have occupied a large portion of Chinese temporary residents in Australia [13]. With the economic development, the increasing number of Chinese parents especially the middle class and super-rich Chinese would like to send their children to study aboard in the top universities in the world. Australia has the reputation for education in the world. Thus, the number of Chinese international students in Australia has increased. Due to cultural ideology, an international student is likely to become potential investors to take into account purchase a residential real estate when studying in Australia. Thus, temporary migration mobility is expected to have a positive effect on the residential real estate market.

\section{B. Australian Residential Real Estate Market}

Australia is considered with the strong competitiveness of residential destination for foreign investors, especially Asian investors. Many Asians are researching a good location for a better lifestyle. It is believed that Asian will become the largest middle class in the world in the near future [14]. Australia is in a proximate geographic location with the Asia-Pacific region [15], which neighbouring Asian countries. It possibly attracts many middle class investors in Asian countries to purchase a residential real estate in Australia. Importantly, compared to neighbouring nations of Asia, the price of Australian real estate is considered to be reasonable [16]. Particularly, Australian real estate is often marketed as having 'superiority' with prestige [9], with the title of the world's most liveable city in the world in the past 6 years [17]. Additionally, the Australian education with famous universities in the world became a special competitiveness of residential destination for foreign investors. Individuals who study in Australian or plan to study in Australian in the future are likely to invest in an Australian residential real estate. Geographic location, reasonable price, liveable environment and good education in Australia are attracting new middle class and super-rich investors into the residential real estate market.

Australian residential real estate prices have surged on the average of $7.25 \%$ per year over the last 30 years. The median real estate price in Sydney was around AU\$400,000 in 2002. A large amount of foreign investment has invested the Australian residential real estate after the Global Financial Crisis in 2008. The median real estate price in Sydney increased from around AU\$500,000 in 2008 to around AU\$1,000,000 in 2017. Chinese investment was the top of foreign investment in the Australian residential real estate market. Thus, it is often claimed that Chinese investment has had a negative effect on the Australian residential real estate as it is suspected to cause the housing affordability issues for domestic buyers, as reported by the media. In order to reduce Australia residential real estate prices, the foreign investment rules became stricter for purchasing Australian residential real estate [18]. However, Chinese investors only accounted for less 2 percent of the Australian residential real estate transaction [19]. It is questionable that the small proportion of Chinese investment has had a significant effect on the Australian residential real estate price. Importantly, under the Foreign Investment Review Board ${ }^{1}$ (FIRB), foreign investors who are not a temporary resident are only allowed to purchase new or off-the-plan residential real estate in Australia. Even the foreign investor is a 'temporary resident, he or she can only purchase one established residential real estate to use as a residence while he lives in Australia instead of investment purpose [20]. Thus, it is argued that the increase of Chinese investment positively affects the development of the Australian residential real estate market.

\section{The Relationship Between Tourism and Residential Real Estate Market}

A rapid increase in global tourism is impacting foreign investment in global residential real estate investment [12]. The most common findings for global real estate investment are that tourism can positively contribute to the local residential real estate market. A study using a system generalized method of moments method to analysis 103 Italian cities found that tourism activity could push up the local house prices [21]. In terms of real estate construction, international tourism can push the growth of foreign investment in real estate property and then facilitate the development of building construction in the local real estate sector [22]. While tourism development raises the demand for residential real estate According to the researcher [23], the supply of real estate is fixed in the short run, leading to the increase of real estate prices [11]. In Australia, international tourists are identified as-as 'all other foreign persons in FIRB, who only allow to purchase new or off-the-plan residential real estate [24]. It is possible that this kind of investors contributes to the development of Australian real estate construction without being speculative in nature in Australia [25].

\section{The Relationship Between Temporary Migration and The Residential Real Estate Market}

There have been a few recent studies of temporary migration and residential real estate market. One study using American data shows that migration increase the housing demand, lead to increasing housing prices [26]. Similarly, other study of European cities shows that migration has a negative impact on the issue of affordability in the local real estate market [27]. In terms of residential real estate regulations in Australia, temporary residents are allowed to purchase only one established residential real estate for living purpose. It is possible that this kind of investors increases the housing price of Australia residential real estate. However, it is suggested that the impact of foreign investment on the residential real estate price was trivial, as they only purchase one established residential real estate. In addition, temporary migrations increase the housing demand, which is likely to contribute to

The FIRB is a non-statutory body established in 1976 to advise the Treasurer and the Government on Australia's Foreign Investment Policy and its administration [31]. 
the development of building construction in Australian residential real estate markets.

\section{Methodology AND DATA}

\section{A. Research Method}

The ARDL model is introduced to examine the cointegration relationship between Chinese individual mobility and the Australian residential real estate market by Eviews 10.0 software in this study. The ARDL model is one of the cointegration methods to examine whether a long-run relationship exists [28]. If it is proved the existence of the longrun relationship exists, the short-run and long-run coefficients can be investigated. There are three major reasons for selecting this model. Firstly, a small sample size is accepted to examine by the model in presenting more reliable results. It is different with other cointegration methods with a large sample size for validity such as Johansen cointegration. Secondly, integrated I(0) or I(1) variables can be tested through the method [28]. Thirdly, the short-run and long-run coefficients can be investigated simultaneously in the model [28].

There are three main steps in the ARDL modelling process. Firstly, stationarity of all the series should be tested by unit root test. Unit root test determines whether the suitability of the ARDL model. Secondly, it is used the bound testing to compute the F-statistics to confirm whether the long-run relationship exists among the variables. The typical ARDL model to cointegration proposed by (1) [28]:

$$
\begin{aligned}
\Delta \operatorname{Ln} Y_{t}= & c+\sum_{i=1}^{k_{1}} \alpha \Delta \operatorname{Ln} Y_{t-i}+\sum_{i=1}^{k_{2}} \beta \Delta \operatorname{Ln} X_{t-i}+\sum_{i=1}^{k_{3}} \gamma \Delta L n Z_{t-i} \\
& +\delta \operatorname{Ln} Y_{t-1}+\sigma \operatorname{Ln} X_{t-1}+\phi L n Z_{t-1}+\tau_{t}
\end{aligned}
$$

Where $\mathrm{c}$ is the drift term; $\Delta$ is the first difference operator; $\tau$ is the white noise error term. All the series are in natural logarithmic form ( $\mathrm{Ln})$. The bound testing is based on F-test, which is used to test the presence of a long-run relationship. The F-test is a test of the null hypothesis. It can be shown as follow:

$$
\text { Null Hypothesis: H0: } \delta=\sigma=\phi=0
$$

\section{Alternative Hypothesis: H1: $\delta \neq \mathbf{0}$ or $\sigma \neq \mathbf{0}$ or $\phi \neq 0$}

If the null hypothesis is rejected, cointegration among the variables exists. The short-run and long-run relationships among variables can be calculated by the ARDL model if the cointegration among the variables exists. Thirdly, the long-run and short-run coefficients can be calculated by the ARDL model and the error correction model (ECM). The ARDL for the long-run model can be expressed as (2):

$\operatorname{LnY}_{t}=\mathrm{c}+\sum_{\mathrm{i}=1}^{\mathrm{k}_{1}} \alpha \Delta \operatorname{LnY_{t-i}}+\sum_{\mathrm{i}=1}^{\mathrm{k}_{2}} \beta \Delta \operatorname{LnX} X_{t-i}+\sum_{\mathrm{i}=1}^{\mathrm{k}_{3}} \gamma \Delta \operatorname{LnZ_{t-i}}+\tau_{t}$

Where $\alpha, \beta, \gamma$ are long-run coefficients of the ARDL model. The ARDL for the short-run coefficients by the ECM model as listed in (3):
$\Delta \operatorname{LnY} Y_{t}=\mathrm{c}+\sum_{\mathrm{i}=1}^{\mathrm{k}_{1}} \alpha \Delta \operatorname{Ln} Y_{t-i}+\sum_{\mathrm{i}=1}^{\mathrm{k}_{2}} \beta \Delta \operatorname{Ln} X_{t-i}+\sum_{\mathrm{i}=1}^{\mathrm{k}_{3}} \gamma \Delta \operatorname{LnZ} Z_{t-i}+\varepsilon \mathrm{ECM}_{t-i}+\tau_{t}$

Where $\alpha, \beta, \gamma$ are short-run coefficients of the ARDLECM model; ECM is the error-correction term; $\varepsilon$ is the speed of adjustment parameter.

\section{B. Data}

This study has incorporated the most important variables, which are the Chinese tourism mobility and temporary migration. It may be affected by the inflows of Chinese investments in the Australian residential real estate markets. Therefore, the study examines the nature of the relationship (long-run and short-run) that exists between the inflows of Chinese tourists, Chinese temporary residents, and Australian residential real estate market during the period 1994-2016. As a measure of the Australian residential real estate market, we use gross value added of building construction and mean residential real estate prices. The annual time-series data for gross value added for building construction and mean residential real estate prices, the number of Chinese tourists and temporary residents from 1994 to 2016 was collected from Australian Bureau of Statistics. One of the dependent variables is defined as the residential real estate price. The residential real estate price is adopted median price of eight capital cities in Australian and then averaged these median prices as the mean price of residential real estate price in Australia. The mean price of the residential real estate is represented by HP. Another dependent variable is defined as the real estate construction, which impact of the performance of the real estate sector. The real estate construction is adopted gross value added of building constructions in Australia, which is represented by CON. The study focuses on two important variables, Chinese tourism and temporary migration, affecting in Australian residential real estate market. Thus, one explanatory variable is the Chinese tourism in Australia. We use the number of Chinese tourists into as the measure. TOUR is used to represent Chinese tourists. Another explanatory variable is the Chinese temporary migration in Australia. We use the number of Chinese temporary residents as the measure. TEM is used to represent Chinese temporary residents. Thus, An ARDL representation of this study is shown as follows:

$$
\begin{aligned}
& \Delta \operatorname{LnHP}_{t}=\mathrm{c}+\sum_{\mathrm{i}=1}^{\mathrm{k}_{1}} \alpha \Delta L n H P_{t-i}+\sum_{\mathrm{i}=1}^{\mathrm{k}_{2}} \beta \Delta \operatorname{LnTOUR_{t-i}}+\sum_{\mathrm{i}=1}^{\mathrm{k}_{3}} \gamma \Delta \operatorname{LnTEM_{t-i}} \\
& +\delta \mathrm{LnHP}_{t-1}+\sigma n \mathrm{TOUR}_{t-1}+\phi \operatorname{LnTEM}_{t-1}+\tau_{t} \\
& \Delta \operatorname{LnCON}_{t}=\mathrm{c}+\sum_{\mathrm{i}=1}^{k_{1}} \alpha \Delta L n \mathrm{HC}_{t-i}+\sum_{\mathrm{i}=1}^{\mathrm{k}_{2}} \beta \Delta \operatorname{LnTOUR_{t-i}}+\sum_{\mathrm{i}=1}^{k_{3}} \gamma \Delta \operatorname{LnTEM_{t-i}} \\
& +\delta \mathrm{LnHC}_{t-1}+\sigma \mathrm{Ln} \mathrm{TOUR}_{t-1}+\phi \operatorname{LnTEM}_{t-1}+\tau_{t}
\end{aligned}
$$

\section{RESULTS}

\section{A. Unit Root Test}

At the first step, stationarity of all the series variables is tested before employing time series econometric models [29]. For this reason, the augmented Dickey-Fuller (ADF) test was 
employed for the four variables, including Australian residential real estate price, Australian real estate construction, Chinese tourists and Chinese temporary residents. The test result is presented in Table $\mathrm{I}$. As shown in Table $\mathrm{I}$, all variables are into I (1) at the 1 percent and 5 percent significant levels after taking the first difference. It indicates that LnHP, LnCON, LnTOUR and LnTEM conform to I(1). Thus the ARDL model can be used.

TABLE I. RESULTS OF ADF TEST

\begin{tabular}{|l|l|l|}
\hline \multicolumn{1}{|c|}{ Variables } & \multicolumn{1}{c|}{ Constant } & Constant and Trend \\
\hline \multicolumn{1}{|c|}{ Level } & & \\
\hline LnHP & -0.513909 & -0.954065 \\
\hline LnCON & -1.057910 & -1.606994 \\
\hline LnTOUR & -1.987858 & -3.028131 \\
\hline LnTEM & $-2.785456^{*}$ & 0.306346 \\
\hline $\begin{array}{c}\text { First } \\
\text { Difference }\end{array}$ & & \\
\hline LnHP & $-3.261127^{* *}$ & -3.256352 \\
\hline LnCON & $-4.344049 * * *$ & $-4.397770^{* *}$ \\
\hline LnTOUR & $-4.859851^{* * *}$ & $-4.895888^{* * *}$ \\
\hline LnTEM & $-2.843579 *$ & $-4.317260^{* *}$ \\
\hline \multicolumn{2}{|c|}{ a. ***,**** imply significance at the $1 \%, 5 \%, 10 \%$ level, respectively } \\
& \multicolumn{2}{c}{ b. The lag length for the ADF was selected using AIC }
\end{tabular}

\section{B. Bound Testing}

At the second steps, the bound testing is adopted to ascertain whether a long-run relationship among the variables exists. The null hypothesis for no cointegration would be accepted when the calculated values fall below the lower bound. By contrast, the null hypothesis would be rejected when the calculated values exceed the upper bound. If the calculated value is within the two bounds, the test cannot be inconclusive and the further assessment is required. In this study, the bounds values are used by Narayan instead of Pesaran due to the small size of the sample [30]. The testing results are provided in Table II.

The value of $\mathrm{F}_{\mathrm{p}}(\mathrm{HP} / \mathrm{TOUR}, \mathrm{TM})$ is 6.33 and the value of $\mathrm{F}_{\mathrm{p}}$ (HC/TOUR, TM) is 5.69. Both of the values are higher than the upper level at the 5 percent significance level. The null hypothesis is strongly rejected. It means a long-run relationship exists in (4) and (5).

TABLE II. RESULTS OF BOUNDS TESTING

\begin{tabular}{|l|l|l|}
\hline \multicolumn{1}{|c|}{ F-statistic } & \multicolumn{1}{c|}{ Value } & \multicolumn{1}{c|}{ K } \\
\hline $\boldsymbol{F}_{\boldsymbol{F}}($ HP/TOUR,TEM $)$ & 6.334977 & 2 \\
\hline $\boldsymbol{F}_{\boldsymbol{F}} /$ TOUR,TEM $)$ & 5.691473 & 2 \\
\hline Critical Value Bounds & $\begin{array}{l}\text { Lower } \\
\text { Bound }\end{array}$ & Upper Bound \\
\hline Significance & 3.38 & 4.02 \\
\hline $10 \%$ & 3.88 & 4.61 \\
\hline $5 \%$ & & \\
\hline
\end{tabular}

\section{Estimation of the ARDLModel}

Bound Testing ascertains the existence of a long-run relationship. Thus, the ARDL model is introduced to estimate the long-run coefficients and the ARDL-ECM model is used to calculate the short-run coefficients.

1) Australian residential real estate prices as a dependent variable: For the long-run coefficients, the results are presented in Table III and IV. The model for the Australian residential real estate price is ARDL $(1,2,3)$. As shown in Table III, the long-run coefficients of Chinese temporary residents and Chinese tourists are 0.32 and 2.72 , respectively. It means that a 1 percent increase of Chinese temporary residents leads to a 0.32 percent increase in Australian residential real estate prices and a 1 percent increase of Chinese tourists leads to a 2.27 percent increase in Australian residential real estate prices. However, at the $5 \%$ significance level, the relationship between Chinese temporary residents and Australian residential real estate prices, and the relationship between Chinese tourists and Australian residential real estate prices are not significant in the long run. In terms of the short-run relationship, the result is calculated from the (3) are shown in Table IV. It is implied that the system could be back to long-term equilibrium after a shortterm shock. The study results show that the change in the coefficient of dLnTEM(-1) and dLnTEM (-2) does have a significant effect on the Australian residential real estate price in the short run. The coefficient of last year's Chinese temporary residents two years ago is negatively related to the current year's Australian residential real estate price. But the last two year's Chinese temporary residents are positively and significantly related to the current year's the Australian residential real estate price. In terms of the coefficient of dLnTOUR, a 1 percent increase of Chinese tourists increased the Australian residential real estate price by 0.21 percent in short-run. The ECM coefficient is -0.13 and is significant at $1 \%$ level.

TABLE III. ESTIMATED LONG-RUN COEFFICIENTS :HOUSIGN PRICES AS A DEPENDENT VARIABLE

\begin{tabular}{|l|l|l|}
\hline \multirow{2}{*}{ Variables } & \multicolumn{2}{|c|}{$\begin{array}{c}\text { ARDL(1,2,3); Dependent Variable } \\
\text { (LnHP) }\end{array}$} \\
\cline { 2 - 3 } & \multicolumn{1}{|c|}{ Coefficient } & \multicolumn{1}{c|}{ Standard Error } \\
\hline LnTEM & 0.324975 & 0.863596 \\
\hline LnTOUR & 2.715879 & 0.503624 \\
\hline
\end{tabular}

2) Australian real estate construction as a dependent variable: Considering Australian real estate construction as a dependent variable, the long-run coefficients of the ARDL $(1,1,2)$ are presented in Table V. As shown in Table V, the negative relationship between the Chinese tourists and the Australian real estate construction. A 1 percent increase of Chinese tourists leads to a 0.39 percent decrease in the Australian real estate construction at the $5 \%$ significance level in the long run. The relationship between Chinese temporary 
residents and the Australian real estate construction is not significant in the long run. Additionally, Table VI displays the results for the short-run coefficients. It shows that the coefficient of dLnTEM (-0.25) is negatively related with the Australian real estate construction in the short run. The coefficient of dLnTOUR(-1) implies that Chinese tourists have a negative and significant effect on the Australian real estate construction in the short-run. This means a 1 percent increase of last year's Chinese tourists decreased the current year's Australian real estate construction by 0.39 percent keeping other things being equal.

TABLE IV. ERROR CORRECTION REPRESENTATION: HOUSIGN PRICES AS A DEPENDENT VARIABLE

\begin{tabular}{|l|l|l|}
\hline \multirow{2}{*}{\multicolumn{2}{|c|}{ Variables }} & \multicolumn{2}{|c|}{$\begin{array}{c}\text { ARDL(1,2,3); Dependent Variable } \\
\text { (dLnHP) }\end{array}$} \\
\cline { 2 - 3 } & \multicolumn{1}{|c|}{ Coefficient } & \multicolumn{1}{c|}{ Standard Error } \\
\hline ECM(-1) & -0.132575 & $-5.739502 * * *$ \\
\hline dLnTEM & -0.064683 & -0.698746 \\
\hline dLnTEM(-1) & -0.246495 & $-2.426260 * *$ \\
\hline dLnTEM(-2) & 0.339290 & $3.621748 * * *$ \\
\hline dLnTOUR & 0.213260 & $3.012494 * *$ \\
\hline dLnTOUR (-1) & -0.121761 & -1.725192 \\
\hline
\end{tabular}

TABLE V. ESTIMATED LONG-RUN COEFFICIENTS :HOUSIGN PRICES AS A DEPENDENT VARIABLE

\begin{tabular}{|l|l|l|}
\hline \multirow{2}{*}{ Variables } & \multicolumn{2}{|c|}{$\begin{array}{c}\text { ARDL(1,1,2); Dependent Variable } \\
\text { (LnCON) }\end{array}$} \\
\cline { 2 - 3 } & \multicolumn{1}{|c|}{ Coefficient } & Standard Error \\
\hline LnTEM & 0.057373 & 0.280720 \\
\hline LnTOUR & 0.650266 & $3.006045^{* *}$ \\
\hline
\end{tabular}

e. $* * *, * *, *$ imply significance at the $1 \%, 5 \%, 10 \%$ level, respectively

TABLE VI. ERROR CORRECTION REPRESENTATION: HOUSIGN PRICES AS A DEPENDENT VARIABLE

\begin{tabular}{|l|l|l|}
\hline \multirow{2}{*}{\multicolumn{2}{|}{ Variables }} & \multicolumn{2}{|c|}{$\begin{array}{c}\text { ARDL(1,1,2); Dependent Variable } \\
\text { (dLnCON) }\end{array}$} \\
\cline { 2 - 3 } & \multicolumn{1}{|c|}{ Coefficient } & \multicolumn{1}{c|}{ Standard Error } \\
\hline ECM(-1) & -0.593766 & $-5.293351 * * *$ \\
\hline dLnTEM & -0.245956 & $-1.777787 *$ \\
\hline dLnTOUR & 0.021319 & 0.193298 \\
\hline dLnTOUR(-1) & -0.385498 & $-3.293292 * * *$ \\
\hline
\end{tabular}

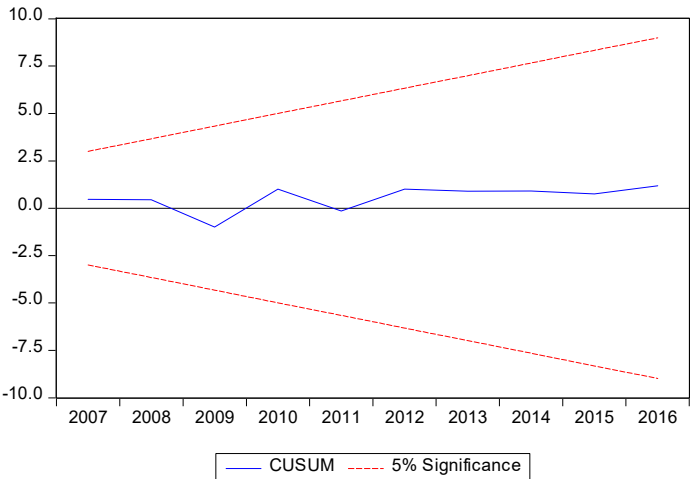

Fig. 1. Australian residential real estate prices as a dependent cariable CUSUM based on ARDL(1,2,3).

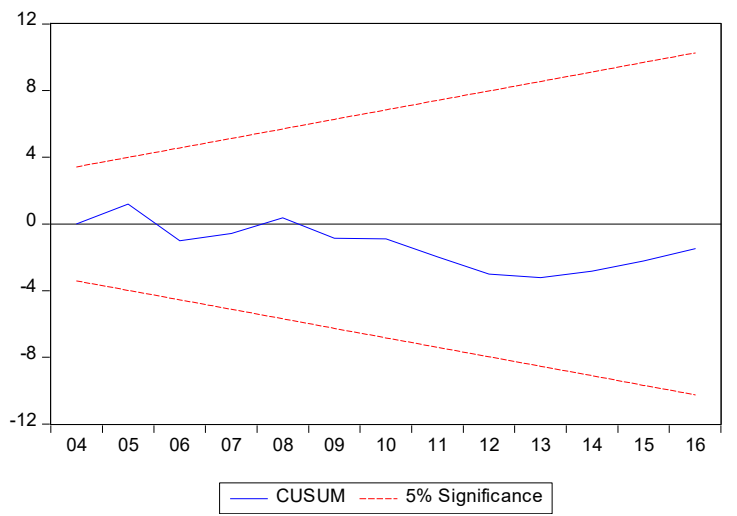

Fig. 2. Australian real estate construction as a dependent cariable CUSUM based on ARDL $(1,1,2)$.

\section{Stability Test}

In the last step, the stability test is required to confirm the stable short-run and long-run relationship. The cumulative sum (CUSUM) is used for the estimated ARDL models for the Australian residential real estate price and the Australian real estate construction as a dependent variable. The result is shown in Fig. 1 and 2. The assessment shows the CUSUM plots lies between the 5 percent critical bound lines, which implies the stability of short-run and long-run coefficients of the selected ARDL. As shown in Fig. 1, all models are reliable, which can be used for further investigation.

\section{CONCLUSION AND DISCUSSION}

By using the ARDL model, a long-term relationship among Chinese temporary residents, Chinese tourists and the Australian residential real estate market is revealed. The time series of the data was from 1994 to 2016 with 22 observations. From the results, the major finding is that Chinese tourism mobility and temporary migration mobility lead to the increase of Australian residential real estate prices and have a negative effect on the Australian real estate construction in the short-run. In terms of long-run relationship, Chinese tourism mobility and temporary migration mobility does not have a significant and positive effect on Australian residential real estate prices. But Chinese tourism mobility contributes to the development of the Australian real estate construction in the long run. It is believed that the fixed supply of real estate in the short run is not enough 
for the demand for residential real estate from the big volume of Chinese individual mobility. Thus the big volume of Chinese individual mobility pushed up the Australian residential real estate price but adversely affected the development of real estate construction in the short-run. After a short period, Chinese individual mobility has become an insignificant effect on Australian residential real estate prices. It is because Chinese is accounted for a small proportion of Australian residential real estate transaction. The small proportion of investment is little effect on the Australian residential real estate price in the long-run. Additionally, the original purpose of introducing foreign investment is to increase the supply in the Australian residential real estate market in order to reduce or sustain the real estate price under the FIRB policy [31]. The finding supports this argument. It indicates that a positive and significant relationship between Chinese tourism mobility and the development of the Australian real estate construction. Thus it is suggested that Chinese individual mobility does not boost the Australian residential real estate price, but also there have been some positive influences on increasing residential real estate stock. Thus, this study offers important practical insights for Chinese individual mobility in Australian residential real estate. Understanding the effect of Chinese individual mobility in the Australian residential real estate market, policymakers can used Chinese individual mobility, as an extra form of capital, to reduces the risk of price booms, issues of unaffordability and efficiency of the residential real estate market, as long as the process is governed in the correct manner by local government.

\section{REFERENCES}

[1] D. Held, A Globalizing World: Culture, Economics, Politics. Routledge, 2004.

[2] F.V. Noorloos, "Residential tourism and multiple mobilities: Local citizenship and community fragmentation in Costa Rica," Sustainability, vol.5(2), pp. 570-589, 2013.

[3] I. Koch-Weser and G. Ditz, "Chinese investment in the United States: Recent trends in real estate, industry, and investment promotion," USChina Economic and Security Review Commission, pp. 9, 2015.

[4] K. Sun, "Foreign investment in real estate in Canada," China Institute Occasional Paper Series, vol. 2(3), 2015.

[5] D. Rogers, C.L. Lee, and D. Yan, "The politics of foreign investment in Australian housing: Chinese investors, translocal sales agents and local resistance," Housing Studies, vol. 30(5), pp. 730-748, 2015.

[6] J. Dunning and S.M. Lundan, Multinational Enterprises and the Global Economy. Edward Elgar Publishing, 2008.

[7] A.S. Rausch, "Place branding in rural Japan: Cultural commodities as local brands," Place Branding and Public Diplomacy, vol. 4(2), pp. 136146, 2008.

[8] R. Brown, J. Flaherty, and R. Lombardo, "Determination of the maximum affordable price for negatively geared investments in residential property," Pacific Rim Property Research Journal, vol. 8(4), pp. 300, 2002 .
[9] A. Richards, "Improving median housing price indexes through stratification," Journal of Real Estate Research, 2008.

[10] P. Wong, Drivers of Overseas Investments in the Australian Residential Property Market, 2016.

[11] H.G. Fereidouni and T.A. Masron, "Real estate market factors and foreign real estate investment," Journal of Economic Studies, vol.40, no.4, pp. 448-468, 2013.

[12] E.C. Hui and K.K.K. Chan, "Foreign direct investment in China's real estate market," Habitat International, vol. 43, pp. 231-239, 2014

[13] ABS, Australian Demographic Statistics, Available at: http://www.abs.gov.au/AUSSTATS/abs@.nsf/mf/3101.0, 2017.

[14] K. Henry, "Australia in the Asian century," Asia \& the Pacific Policy Studies, vol. 3(2), pp. 132-139, 2016.

[15] J.Helliwell, H. Huang, and S. Wang, "The geography of world happiness," World Happiness Report 2015, pp. 16-17, 2015

[16] M.A. Goldberg, R.L. Heinkel, and M.D. Levi, "Foreign direct Investment: The human dimension," Journal of International Money and Finance, vol. 24, pp. 913-834, 2005.

[17] P. Wright, "Melbourne ranked world's most liveable city for sixth onsecutive year by EIU," ABC News. Available at: http://www.abc.net.au/news/2016-08-18/melbourne-ranked-worldsmost-liveable-city-for-sixth-year/7761642, 2016.

[18] E. Kitson, K. Thomson, and V. Chaplin, "An overview of Australia's housing market and residential mortgage: Backed securities," S\&P Global Market Intelligence, 2015.

[19] D. Chau, "Are Chinese buyers driving up Australia's housing prices," ABC NEWS, 2017

[20] S. Kim and D.Y. Yang, "Do capital inflows matter to asset prices The case of Korea," Asian Economic Journal, vol. 23, pp. 323-348, 2009.

[21] B. Biagi, M.G. Brandano, and D. Lambiri, "Does tourism affect house prices: Evidence from Italy," Growth and Change, vol. 46(3), pp. 501$528,2015$.

[22] F. Díaz Orueta and M.L. Lourés Seoane, Housing, tourism and the real estate sector: The Spanish Mediterranean Coast, 2007.

[23] M.P. Barrantes-Reynolds, "The expansion of "real estate tourism" in coastal areas: Its behaviour and implications," Recreation and Society in Africa, Asia and Latin America, vol. 2(1), 2001

[24] W.C. McGaghie, G. Bordage, and J.A. Shea, "Problem statement, conceptual framework, and research question," Academic Medicine, vol. 76(8), pp. 923-924, 2001.

[25] M. Thirlwell, Is the Foreign Investment Review Board acting fairly?, Lowy Institute for International Policy, Sydney, 2008.

[26] A. Saiz, "Immigration and housing rents in American cities," Journal of Urban Economics, vol. 61(2), pp. 345-371, 2007.

[27] L. Goodson, S. Thomas, J. Phillimore, and S. Pemberton, Mass Migration and Real Estate in European Cities, Urban Land Institute, 2017.

[28] M.H. Pesaran, Y. Shin, and R.J. Smith, "Bounds testing approaches to the analysis of level relationships," Journal of Applied Econometrics, vol. 16(3), pp. 289-326, 2001.

[29] C.W. Granger, "Some properties of time series data and their use in econometric model specification," Journal of Econometrics, vol. 16(1), pp. 121-130, 1981.

[30] P.K. Narayan, "The saving and investment nexus for China: evidence from cointegration tests," Applied Economics, vol. 37, pp.1979-1990, 2005 .

[31] FIRB, Annual Report 2013-14, 2015. 